\title{
Prevalence and Genetic Diversity of Toxoplasma gondii in Free-Ranging Chickens from the Caribbean
}

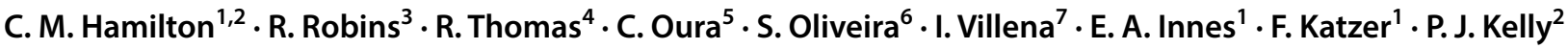

Received: 4 March 2019 / Accepted: 6 May 2019 / Published online: 20 May 2019

(c) The Author(s) 2019

\begin{abstract}
Purpose Toxoplasma gondii is a zoonotic parasite capable of infecting a wide range of hosts. Free-range chickens are important sentinels in the epidemiology of this parasite as they feed from the ground and are likely to ingest oocysts shed in the faeces of infected cats. Atypical strains of $T$. gondii are known to dominate in South America where they are associated with more severe disease in humans, yet relatively little is known about the strains circulating in neighbouring Caribbean islands. Methods In this study, hearts and brains were collected from free-range chickens in Antigua and Barbuda $(n=45)$, Dominica $(n=76)$ and Trinidad $(n=41)$, and DNA was extracted for nested ITS1 PCR and PCR-RFLP. Sera were collected and screened for antibodies using the modified agglutination test (MAT).

Results Antibodies to T. gondii were detected in 20.5, 38.2 and 17.1\% of chickens in Antigua and Barbuda, Dominica and Trinidad, respectively. Toxoplasma gondii DNA was also detected by PCR in 24.4, 17.1 and 17.1\% of chickens, respectively, giving an overall prevalence of 31.1, 42.1, and 29.3\% for each of the 3 island nations. Results of PCR-RFLP revealed 2 new atypical genotypes (designated ToxoDB \#281 and \#282) and one Type III (ToxoDB \#2) in chickens from Antigua. Partial genotyping of a further 8 isolates ( 7 from Antigua and one from Trinidad) revealed different allele-types at five or more markers for 7 of the isolates, suggesting atypical genotypes.

Conclusions This is the first study to report the prevalence of T. gondii in free-range chickens in Antigua and Barbuda, Dominica and Trinidad and Tobago. It is also the first to report the presence of atypical genotypes in Antigua and Barbuda and Trinidad and Tobago.
\end{abstract}

Keywords Toxoplasma gondii $\cdot$ Chickens $\cdot$ Antigua and Barbuda $\cdot$ Dominica $\cdot$ Trinidad and Tobago

\section{Introduction}

The zoonotic protozoan parasite, Toxoplasma gondii, is ubiquitous worldwide where it can cause infection in almost all warm-blooded animals. Felids are the only known definitive hosts capable of shedding oocysts in their faeces and contaminating the environment [30]. In humans, transmission

C. M. Hamilton

Clare.Hamilton@moredun.ac.uk

1 Moredun Research Institute, Pentlands Science Park, Midlothian EH26 OPZ, UK

2 School of Veterinary Medicine, Ross University, Island Main Road, West Farm, Saint Kitts and Nevis

3 Pioneer Kennels and Veterinary Clinic, St. Johns, Antigua and Barbuda

4 Livestock Development Unit, Ministry of Agriculture and Environment, Botanical Gardens, Roseau, Dominica routes of the parasite include ingestion of sporulated oocysts from water or unwashed contaminated food, ingestion of tissue cysts in raw or undercooked infected meat, or vertical transmission from mother to foetus during a primary infection. Chickens are important hosts in the epidemiology of $T$. gondii because they feed from the ground and are likely to ingest oocysts, making them good sentinels for

5 Department of Basic Veterinary Sciences, School of Veterinary Medicine, The University of the West Indies, Eric Williams Medical Sciences Complex, Mount Hope, Trinidad and Tobago

6 Department of Preventive Veterinary Medicine and Animal Health, School of Veterinary Medicine, University of São Paulo, São Paulo, Brazil

7 Laboratory of Parasitology, National Reference Centre on Toxoplasmosis, EA 7510, University Reims Champagne Ardenne and Hospital Maison Blanche, CHU Reims, Reims, France 
environmental contamination. In 2002, a survey of $T$. gondii in free-roaming chickens was initiated with the goal of characterising the genetic diversity of $T$. gondii on a global basis $[14,18]$. Consequently, free-ranging chickens are widely used to study the prevalence and genetic variation of T. gondii worldwide [10, 36-38].

Previous research has shown that isolates of $T$. gondii from Central and South America are genetically distinct from the clonal lineages that dominate in North America and Europe [3,33], and they are more associated with severe disease, even in immune competent people [8]. Studies in the Caribbean have demonstrated a high seroprevalence of T. gondii in livestock [9, 27, 28], chickens [10, 29], cats [21] and dogs [22, 23] and that atypical strains are more common than previously thought [29]. Seroprevalence data for humans in the region are lacking; however, a recent study involving 10 Caribbean islands revealed that pregnant women in Antigua and Barbuda, and Dominica had some of the highest seroprevalence rates recorded in the study [23]. It is not known what genotypes are circulating on these islands or how widespread $T$. gondii oocyst contamination is; therefore, the aim of this study was to use free-ranging chickens to investigate the prevalence and genetic diversity of T. gondii on four Caribbean islands.

\section{Materials and Methods}

\section{Sampling Locations}

Antigua and Barbuda is a twin island country $\left(440 \mathrm{~km}^{2}\right)$ in the Leeward Islands in the Eastern Caribbean $\left(17^{\circ} 5^{\prime} \mathrm{N}\right.$, $61^{\circ} 46^{\prime} \mathrm{W}$ ) with a population of approximately 101,000 . Until 2017, over 1600 people inhabited Barbuda; however, following hurricane Irma the island is now virtually uninhabited. They are low-lying islands with an average annual rainfall of $990 \mathrm{~mm}$ and an average temperature of $26.7^{\circ} \mathrm{C}$. Dominica $\left(761 \mathrm{~km}^{2}\right)$ is in the Windward Islands in the Eastern Caribbean $\left(15^{\circ} 25^{\prime} \mathrm{N}, 61^{\circ} 18^{\prime} \mathrm{W}\right)$ and has a population of approximately 73,500 . The island is more mountainous with tropical rainforests and an average annual rainfall of $9000 \mathrm{~mm}$ and an average temperature of $26.3{ }^{\circ} \mathrm{C}$. Trinidad and Tobago is a twin island country in the Windward Islands $\left(10^{\circ} 26^{\prime} \mathrm{N}\right.$, $61^{\circ} 18^{\prime} \mathrm{W}$ ) with a population of approximately 1.4 million. Trinidad is the larger island $\left(4768 \mathrm{~km}^{2}\right)$ and has an average annual rainfall of $1891 \mathrm{~mm}$ and an average temperature of $25.9^{\circ} \mathrm{C}$.

\section{Animals and Ethical Approval}

Chickens (Gallus gallus domesticus) were collected from four different Caribbean islands (representing 3 island nations) following ethical approval from the Institutional Animal Care and Use Committee at Ross University School of Veterinary Medicine (Project Submission 16-5-011). Forty-five free-ranging chickens in Antigua and Barbuda (collected April 2016) and seventy-six free-ranging chickens in Dominica (collected August-October 2016) were collected from each parish around the island with permission from the Chief Veterinary Officers on each island (Dr. Tubal Edwards and Dr. Reginald Thomas, respectively). In Trinidad, forty-one chickens were collected from five backyard poultry farms as part of a separate study [6].

\section{Sample Collection and Processing}

Following humane euthanasia, blood (for serum isolation), heart and brain were collected from each chicken and processed as described previously [29]. Sera were sent to the Toxoplasma National Reference Centre (Reims, France) to be tested for antibodies to $T$. gondii using a modified agglutination test $[17,20,34]$. The MAT antigen was prepared based on previously described methods $[13,17]$. An antibody titre of greater than or equal to 1:6 was considered positive for exposure to $T$. gondii. DNA extraction was performed on $400 \mu \mathrm{l}$ of digested brain and heart homogenate per chicken and screened for $T$. gondii using a nested PCR targeting the ITS1 region between the $18 \mathrm{~S}$ and 5.8S rRNA genes, as previously described $[7,28,29]$. Any samples which were positive by ITS1 PCR were genotyped using a multiplex nested PCR-RFLP targeting 10 genetic markers, as previously described $[28,29]$.

\section{Statistical Analysis}

Level of agreement between MAT results and ITS1 PCR results was investigated using Chi-square test of association and Cohen's kappa coefficient. Positive agreement (PA), negative agreement (NA) and the proportion of overall agreement $\left(\mathrm{p}_{\mathrm{o}}\right)$ between the two tests were also calculated as follows: $P A=2 a /(2 a+b+c), P N=2 d /(2 d+b+c), p o=a+d /$ $(a+b+c+d)$, with $a, b, c, d$ referring to the positive and negative cell values of the $2 \times 2$ contingency table [5, 32]. For Chisquare analysis, a $P$ value of $<0.05$ was deemed significant. For Cohen's kappa coefficient, the strength of agreement was based on the following categories: $<0.01=$ poor agreement; $0.01-0.20=$ slight agreement; $0.21-0.40=$ fair agreement; $0.41-0.60=$ moderate agreement; $0.61-0.80=$ substantial; $0.81-1.0=$ almost perfect agreement [31] . 
Table 1 Toxoplasma gondii detection by serology and PCR in chickens from Antigua and Barbuda, Dominica and Trinidad

\begin{tabular}{|c|c|c|c|c|c|c|c|c|c|c|c|c|}
\hline \multirow[t]{2}{*}{ Caribbean nation } & \multirow{2}{*}{$\begin{array}{l}\text { No. of } \\
\text { chick- } \\
\text { ens }\end{array}$} & \multicolumn{8}{|c|}{ MAT titre $^{\mathrm{a}}$} & \multirow[t]{2}{*}{ No. of seropositive (\%) } & \multirow{2}{*}{$\begin{array}{l}\text { No. of PCR- } \\
\text { positive (\%) }\end{array}$} & \multirow{2}{*}{$\begin{array}{l}\text { Total no. of posi- } \\
\text { tive chickens }{ }^{b} \\
(\%)\end{array}$} \\
\hline & & $\leq 1: 3$ & $1: 6$ & $1: 10$ & $1: 25$ & $1: 50$ & $1: 100$ & $1: 200$ & $1: 800$ & & & \\
\hline Antigua and Barbuda & 45 & 35 & 2 & 0 & 5 & 1 & 0 & 0 & 1 & $9\left(20.5 \%^{c}\right)$ & $11(24.4 \%)$ & $14(31.1 \%)$ \\
\hline Dominica & 76 & 47 & 5 & 1 & 12 & 6 & 2 & 2 & 1 & $29(38.2 \%)$ & $13(17.1 \%)$ & $32(42.1 \%)$ \\
\hline Trinidad and Tobago & 41 & 34 & 1 & 0 & 4 & 0 & 1 & 1 & 0 & $7(17.1 \%)$ & $7(17.1 \%)$ & $12(29.3 \%)$ \\
\hline
\end{tabular}

${ }^{a}$ MAT titre of $\geq 1: 6$ was deemed seropositive

${ }^{\mathrm{b}}$ Chickens positive either by MAT and/or PCR

${ }^{\mathrm{c}}$ Serology for Antigua and Barbuda is based on 44 samples as no serum could be isolated from one chicken

Table 2 Contingency table demonstrating results of the serological and molecular Toxoplasma gondii from freeroaming chickens from all islands detection methods for

\begin{tabular}{ccrr}
\hline & \multicolumn{2}{l}{ MAT } & \\
\cline { 2 - 4 } & POS & NEG & Total \\
\hline PCR & & & \\
POS & 18 & 27 & 45 \\
NEG & 13 & 103 & 116 \\
Total & 31 & 130 & 161 \\
\hline
\end{tabular}

\section{Results}

\section{Molecular and Serological Detection of T. gondii in Chickens}

Chickens positive for $T$. gondii by MAT and/or PCR were found on all islands (Table 1): 14 out of 45 chickens (31.1\%) in Antigua and Barbuda, 32 out of 76 chickens (42.1\%) in Dominica and 12 out of 41 chickens (29.3\%) in Trinidad. Five chickens from Antigua and Barbuda were positive by PCR, but negative by serology, and 3 chickens were positive by serology, but negative by PCR. In Dominica, 3 chickens were positive by PCR, but negative by serology, and 19 chickens were positive by serology, but negative by PCR. In Trinidad, 5 chickens were positive by PCR but tested negative by MAT, and 4 chickens tested positive by MAT but were negative by PCR (Table 2). Despite the apparent discrepancy between MAT and PCR results, Chi-square analysis revealed a significant association between results of the two tests $\left(\chi^{2}=17.29\right.$, d.f. $\left.=1, P<0.001\right)$. Binomial analysis revealed a high overall agreement between the tests (Table 3); however, Cohen's kappa coefficient demonstrated there was only a fair level of agreement between positive MAT results and positive PCR results $(\kappa=0.3182)$.

\section{Genetic Characterization of T. gondii in Chickens}

A full PCR-RFLP genotype could not be obtained for all samples due to lack of amplification at some of the
Table 3 Level of agreement between results obtained by MAT and PCR

\begin{tabular}{llll}
\hline & $\begin{array}{l}\text { Positive agree- } \\
\text { ment (PA) }\end{array}$ & $\begin{array}{l}\text { Negative agree- } \\
\text { ment (NA) }\end{array}$ & $\begin{array}{l}\text { Overall } \\
\text { agreement } \\
\left(\mathrm{p}_{\mathrm{o}}\right)\end{array}$ \\
\hline $\begin{array}{l}\text { MAT versus } \\
\text { PCR }\end{array}$ & 0.47 & 0.84 & 0.75 \\
\hline
\end{tabular}

markers. Of the 11 chickens from Antigua and Barbuda which tested positive for $T$. gondii by ITS1 PCR, 10 were successfully genotyped at 6 or more markers and the majority appears to have atypical genotypes (Table 4). Two of the genotypes are new and have not been previously described (TgCkAn14, designated ToxoDB \#281, and TgCkAn18, designated ToxoDB \#282; Chunlei Su, personal communication). Isolate TgCkAn19 had a clonal Type III genotype (ToxoDB \#2) and isolate TgCkAn33 had Type III alleles at 8 out of 10 markers indicating a possible clonal Type III genotype. Only 4 of the 13 ITS1 PCRpositive chickens from Dominica could be partially genotyped, but amplification was achieved at too few markers so data are excluded. Only one of the 7 ITS1 PCR-positive chickens from Trinidad could be partially genotyped at 5 markers (Table 4). Of those samples where amplification was achieved at 5 or more markers, the genotypes appear atypical.

\section{Discussion}

The results of this study demonstrate a high exposure to nonclonal genotypes of $T$. gondii in free-ranging and backyard chickens in the Caribbean. Although the sample sizes were not large, chickens were collected from different locations around each island representing most parishes. Seroprevalence results in the present study are consistent with previous studies in the Caribbean that reported seroprevalences of 32\% in free-ranging chickens in St. Kitts [29] and 26.9\% in Grenada [10]. They are also comparable to studies on 


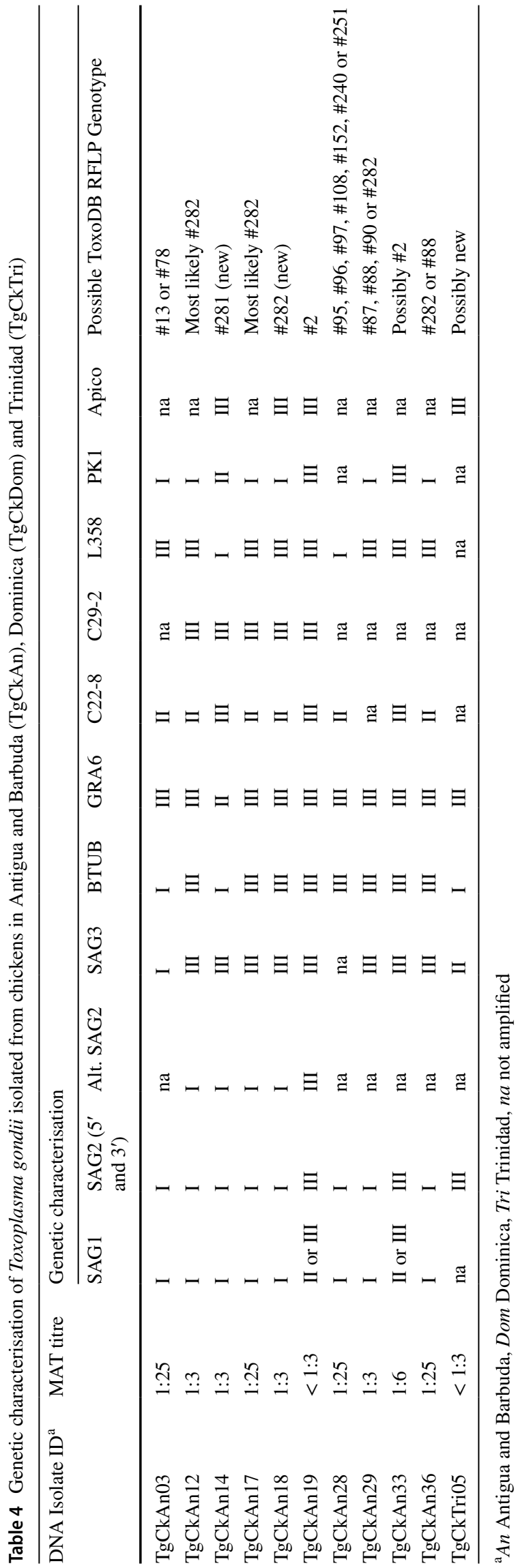

chickens in Indonesia (24.4\%), Poland (30\%) and Vietnam (24.2\%) [19]. Seroprevalence in chickens in Central and South America is high, ranging from 38 to $66 \%$ in South America and 74-85.7\% in Central America [14]. Free-range chickens are important indicators of environmental contamination with $T$. gondii oocysts since they feed from the ground and are thus very likely to come into contact with infected cat faces. The results of the present study strongly suggest that the environments in Antigua and Barbuda, Dominica and Trinidad are contaminated with $T$. gondii oocysts shed by infected cats. Indeed, previous studies of herbivorous livestock in Dominica and Trinidad demonstrated T. gondii seroprevalences of $67.3 \%$ and $35.7 \%$, respectively, in sheep and $58.1 \%$ and $42.9 \%$, respectively, in goats, further attesting to environmental contamination since ingestion of oocysts on contaminated pastures is the main transmission route for these animals $[1,27]$. There are very few data on the prevalence of $T$. gondii in humans in the Caribbean. In a recent study of pregnant women from ten Caribbean islands, anti-Toxoplasma IgG was detected in 32\% (12 out of 38) of women from Antigua and Barbuda, and 59\% (29 out of 49) of women from Dominica [23]. A study of 504 cord blood samples taken from newborns at two hospitals in Trinidad revealed a $T$. gondii seroprevalence of $43.7 \%$ and a questionnaire survey revealed that the highest seroprevalences were in neonates from mothers who owned a cat, practiced outdoor gardening or consumed raw meat [2]. These high levels of human exposure are consistent with the high environmental contamination indicated by the present study and high infection rates in food animals demonstrated in previous studies [1,28].

Unfortunately, a full PCR-RFLP genotyping profile was not achieved for all isolates due to lack of amplification at the single-copy markers. This is a common problem in Toxoplasma research [11] and can only be rectified with the use of a mouse bioassay to amplify the parasites to sufficient levels to achieve complete genotyping, which is not always possible. Although a full PCR-RFLP genotyping profile was not achieved for all samples in the present study, amplification at five or more loci was possible for 11 of the DNA isolates and allowed for the demonstration of a predominance of non-clonal genotypes (i.e., different allele-types at different markers for the same isolate). With the exception of one isolate which had a Type III clonal lineage (TgCkAn19) and one which appeared to have a Type III clonal lineage (TgCkAn33) all of the isolates appeared to be atypical- two of which are new and have not been previously described (\#281 and \#282). Isolates TgCkAn12 and 17 appear to have a similar genetic profile to the new genotype \#282. Isolate TgCkAn03 has a similar profile to ToxoDB RFLP genotype \#13 which has previously been isolated from chickens in St. Kitts [29] and Grenada [10] and has been associated with severe disease in humans $[4,29]$. Our results appear to 
be consistent with previous studies in St. Kitts which have demonstrated a predominance of atypical genotypes in freeranging chickens [29] and the presence of atypical genotypes in cats [21]. However, our results are in contrast to what is observed on the fellow Caribbean island of Grenada where studies in free-range chickens [10,24], dogs [22] and rats [16] have demonstrated a dominance of the Type III clonal lineage. Toxoplasma gondii was previously thought to have a clonal population structure comprising three dominant lineages (Types I, II, III) with very little genetic diversity. However, it is now known that the structure is much more diverse and atypical strains have been reported worldwide, with the majority being reported in Central and South America [35]. The majority of studies on free-roaming chickens in South America have been conducted in Brazil and have demonstrated a predominance of atypical genotypes with few clonal genotypes isolated [12, 15, 25, 37].

From the present study, and previous studies [29], it would appear that the genetic diversity of $T$. gondii in some islands of the Caribbean is similar to that of South America. However, to determine the exact genotypes which are present on the islands in this study, a further study would be needed involving a mouse bioassay and isolation of viable parasites which would allow for full PCR-RFLP profiling.

In this study there was a fair to moderate level of agreement between the MAT results and PCR results. It has been shown previously that $T$. gondii can be isolated from seronegative chickens $[24,29]$ indicating that perhaps the MAT is not appropriate for detecting early infection when levels of IgM are high and IgG are low (and, therefore, undetectable by MAT). A recent study validating the performance of different serological tests in experimentally infected chickens highlighted that the MAT could only consistently detect antibodies in those animals which had been inoculated with $\geq 10^{4} T$. gondii oocysts [34]. Furthermore, the results were dependent on the inoculating strain-with positive MAT results being detected for chickens infected with $10^{3}$ oocysts of the ME49 strain (Type II) but not for chickens infected with $10^{3}$ oocysts of CZ-Tiger strain (Type II) or NED strain (Type III). In the present study there were a number of chickens positive by MAT yet negative by PCR, including one with a titre of 1:800 and two with a titre of 1:200. False negative PCR results could be due to the inhomogeneous distribution of cysts in the digested tissues and the smaller volume of homogenate used for DNA extraction (versus bioassay where all of the homogenate would be used). Chickens are clinically resistant to $T$. gondii so the discrepancy may also be due to a lack of cysts in the tissues [26].

In conclusion, the results of the present study demonstrate the presence of atypical genotypes of $T$. gondii in Antigua and Barbuda and Trinidad and Tobago and that chickens on these islands, as well as on Dominica, are commonly exposed to the parasite, indicating widespread environmental contamination with oocysts. Taken with other data from the region, our study should alert health workers to the presence of $T$. gondii and stimulate public health campaigns urging people, particularly pregnant women, to avoid infections by carefully washing their hands after working with soil, thoroughly cooking their meat and washing fruit and vegetables before consumption.

Acknowledgements The authors would like to thank the Chief Veterinary Officers of Antigua and Barbuda (Dr. Tubal Edwards) and Dominica (Dr. Reginald Thomas) for allowing the study to be carried out. The authors would also like to thank Drs. Payne, Kelsick, Francis, Kellman, Edwards, Hull-James and all the staff of the Pioneer Kennels and Clinic, Antigua, and the Livestock Development Unit, Dominica, for help with the collection of chicken tissues. We also thank Shakera Hemmings, Tashard Major and Rod Suepaul for help with collection of chicken tissues in Trinidad. Funding for this study was provided by Ross University School of Veterinary Medicine, the Moredun Research Institute and the Scottish Government (Rural and Environment Science and Analytical Services Division). SO received a scholarship from the Coordination for the Improvement of Higher Education Personnel (CAPES), Brazil (PDSE, process no. 88881.131561/2016-01).

Authors' contributions CMH and PJK designed the study and made contact with the Chief Veterinary Officers on Antigua and Barbuda and Dominica. RR organized collection and post-mortem of chickens in Antigua and Barbuda. CMH and PJK assisted with post-mortems in Antigua. RT organized for the collection and post-mortem of chickens in Dominica. CO organized for the collection and post-mortem of chickens in Trinidad. CH performed DNA extractions, PCR and RFLP. SO assisted with DNA extraction and RFLP on chickens from Dominica. IV performed the MAT on all serum samples. EAI and FK helped with study design. All authors reviewed the manuscript.

Open Access This article is distributed under the terms of the Creative Commons Attribution 4.0 International License (http://creativecommons.org/licenses/by/4.0/), which permits unrestricted use, distribution, and reproduction in any medium, provided you give appropriate credit to the original author(s) and the source, provide a link to the Creative Commons license, and indicate if changes were made.

\section{References}

1. Adesiyun AA, Cazabon EP (1996) Seroprevalences of Brucellosis, Q-Fever and Toxoplasmosis in slaughter livestock in Trinidad. Rev Elev Med Vet Pays Trop 49:28-30

2. Adesiyun AA, Gooding R, Ganta K, Seepersadsingh N, Ramsewak S (2007) Congenital toxoplasmosis in two health institutions in Trinidad. West Indian Med J 56:166-170

3. Ajzenberg D, Banuls AL, Su C, Dumetre A, Demar M, Carme B, Darde ML (2004) Genetic diversity, clonality and sexuality in Toxoplasma gondii. Int J Parasitol 34:1185-1196. https://doi. org/10.1016/j.ijpara.2004.06.007

4. Ajzenberg D, Year H, Marty P, Paris L, Dalle F, Menotti J, Aubert D, Franck J, Bessieres MH, Quinio D et al (2009) Genotype of 88 Toxoplasma gondii isolates associated with toxoplasmosis in immunocompromised patients and correlation with clinical findings. J Infect Dis 199:1155-1167. https://doi.org/10.1086/59747 7 
5. Al-Kappany YM, Abbas IE, Devleesschauwer B, Dorny P, Jennes M, Cox E (2018) Seroprevalence of anti-Toxoplasma gondii antibodies in Egyptian sheep and goats. BMC Vet Res 14:120-124

6. Brown Jordan A, Narang D, Essen SC, Brookes SM, Brown IH, Oura C (2018) Serological evidence for influenza a virus exposure in wild birds in Trinidad \& Tobago. Vet Sci 5:11-16. https://doi. org/10.3390/vetsci5020050

7. Burrells A, Bartley PM, Zimmer IA, Roy S, Kitchener AC, Meredith A, Wright SE, Innes EA, Katzer F (2013) Evidence of the three main clonal Toxoplasma gondii Lineages from wild mammalian carnivores in the UK. Parasitology 140:1768-1776

8. Carme B, Bissuel F, Ajzenberg D, Bouyne R, Aznar C, Demar M, Bichat S, Louvel D, Bourbigot AM, Peneau C, Neron P, Darde ML (2002) Severe acquired toxoplasmosis in immunocompetent adult patients in French Guiana. J Clin Microbiol 40:4037-4044

9. Chikweto A, Kumthekar S, Tiwari K, Nyack B, Deokar MS, Stratton G, Macpherson CN, Sharma RN, Dubey JP (2011) Seroprevalence of Toxoplasma gondii in pigs, sheep, goats, and cattle from Grenada and Carriacou, West Indies. J Parasitol 97:950-951. https ://doi.org/10.1645/GE-2811.1

10. Chikweto A, Sharma RN, Tiwari KP, Verma SK, Calero-Bernal R, Jiang T, Su C, Kwok OC, Dubey JP (2017) Isolation and RFLP genotyping of Toxoplasma gondii in free-range chickens (Gallus domesticus) in Grenada, West Indies, revealed widespread and dominance of Clonal Type III Parasites. J Parasitol 103:52-55. https://doi.org/10.1645/15-945

11. Cunha MM, Carneiro AC, Costa JG, Vitor RW (2016) Genotyping of Toxoplasma gondii directly from human and animal biological samples: from partial genotypes to a new genotype. J Parasitol 102:157-160. https://doi.org/10.1645/15-813

12. de Oliveira LN, Costa Junior LM, de Melo CF, Ramos Silva JC, Bevilaqua CM, Azevedo SS, Muradian V, Araújo DA, Dubey JP, Gennari SM (2009) Toxoplasma gondii isolates from freerange chickens from the northeast region of Brazil. J Parasitol 95:235-237

13. Desmonts G, Remington JS (1980) Direct agglutination test for diagnosis of toxoplasma infection: method for increasing sensitivity and specificity. J Clin Microbiol 11:562-568

14. Dubey JP (2010) Toxoplasma gondii infections in chickens (Gallus domesticus): prevalence, clinical disease, diagnosis and public health significance. Zoonoses Public Health 57:60-73

15. Dubey JP, Applewhaite L, Sundar N, Velmurugan GV, Bandini LA, Kwok OC, Hill R, Su C (2007) Molecular and biological characterization of Toxoplasma gondii isolates from free-range chickens from Guyana, South America, identified several unique and common parasite genotypes. Parasitology 134:1559-1565

16. Dubey JP, Bhaiyat MI, Macpherson CN, de Allie C, Chikweto A, Kwok OC, Sharma RN (2006) Prevalence of Toxoplasma gondii in Rats (Rattus norvegicus) in Grenada, West Indies. J Parasitol 92:1107-1108. https://doi.org/10.1645/GE-902R.1

17. Dubey JP, Desmonts G (1987) Serological responses of equids fed Toxoplasma gondii oocysts. Equine Vet J 19:337-339

18. Dubey JP, Graham DH, Blackston CR, Lehmann T, Gennari SM, Ragozo AM, Nishic SM, Shena SK, Kwoka OCH, Hilla DE, Thulliez P (2002) Biological and genetic characterisation of Toxoplasma gondii isolates from chickens (Gallus domesticus) from Sao Paulo, Brazil: unexpected findings. Int J Parasitol 32:99-105

19. Dubey JP, Huong LTT, Lawson BWL, Subekti DT, Tassi P, Cabaj W, Sundar N, Velmurugan GV, Kwok OCH, Su C (2008) Seroprevalence and isolation of Toxoplasma gondii from free-range chickens in Ghana, Indonesia, Italy, Poland, and Vietnam. J Parasitol 94:68-71

20. Dubey JP, Laurin E, Kwowk OC (2016) Validation of the modified agglutination test for the detection of Toxoplasma gondii in free-range chickens by using cat and mouse bioassay. Parasitol 143:314-319. https://doi.org/10.1017/s0031182015001316
21. Dubey JP, Moura L, Majumdar D, Sundar N, Velmurugan GV, Kwok OC, Kelly P, Krecek RC, Su C (2009) Isolation and characterization of viable Toxoplasma gondii isolates revealed possible high frequency of mixed infection in feral cats (Felis domesticus) from St Kitts, West Indies. Parasitol 136:589-594

22. Dubey JP, Tiwari K, Chikweto A, Deallie C, Sharma R, Thomas D, Choudhary S, Ferreira LR, Oliveira S, Verma SK, Kwok $\mathrm{OCH}, \mathrm{Su} \mathrm{C}$ (2013) Isolation and RFLP genotyping of Toxoplasma gondii from the domestic dogs (Canis Familiaris) from Grenada, West Indies revealed high genetic variability. Vet Parasitol 197:623-626

23. Dubey JP, Verma SK, Villena I, Aubert D, Geers R, Su C, Lee E, Forde MS, Krecek RC (2016) Toxoplasmosis in the Caribbean Islands: literature review, seroprevalence in pregnant women in ten countries, isolation of viable Toxoplasma gondii from dogs from St. Kitts, West Indies with report of new T. gondii genetic types. Parasitol Res 115:1627-1634. https://doi.org/10.1007/ s00436-015-4900-6

24. Dubey JP, Bhaiyat MI, de Allie C, Macpherson CN, Sharma RN, Sreekumar C, Vianna MC, Shen SK, Kwok OC, Miska KB, Hill DE, Lehmann T (2005) Isolation, tissue distribution, and molecular characterization of Toxoplasma gondii from chickens in Grenada, West Indies. J Parasitol 91:557-560. https://doi. org/10.1645/GE-463R

25. Feitosa TF, Vilela VLR, de Almeida-Neto JL, de Melo LRB, de Morais DF, Alves BF, Nakashima F, Gennari SM, Athayde ACR, de Jesus Pena HF (2017) First report of typical Brazilian Toxoplasma gondii genotypes from isolates of free-range chickens (Gallus gallus domesticus) circulating in the state of Paraíba, Northeast Brazil. Parasitol Res 116:2265-2270

26. Geuthner AC, Koethe M, Ludewig M, Pott S, Schares G, Daugschies A, Bangoura B (2014) Persistence of Toxoplasma gondii tissue stages in poultry over a conventional fattening cycle. Parasitology 141:1359-1364. https://doi.org/10.1017/s00311820140007 $8 \mathrm{x}$

27. Hamilton CM, Katzer F, Innes EA, Kelly PJ (2014) Seroprevalence of Toxoplasma gondii in small ruminants from four Caribbean Islands. Parasit Vectors 7:449-452

28. Hamilton CM, Kelly PJ, Bartley PM, Burrells A, Porco A, Metzler D, Crouch K, Ketzis JK, Innes EA, Katzer F (2015) Toxoplasma gondii in livestock in St. Kitts and Nevis, West Indies. Parasit Vectors 8:166-174. https://doi.org/10.1186/s13071-015-0776-7

29. Hamilton CM, Kelly PJ, Boey K, Corey TM, Huynh H, Metzler D, Villena I, Su C, Innes EA, Katzer F (2017) Predominance of atypical genotypes of Toxoplasma gondii in free-roaming chickens in St. Kitts, West Indies. Parasit Vectors 10:104-112. https://doi. org/10.1186/s13071-017-2019-6

30. Hutchison WM, Dunachie JF, Siim JC, Work K (1969) Life cycle of Toxoplasma gondii. Br Med J 4:806

31. Landis JR, Koch GG (1977) The measurement of observer agreement for categorical data. Biometrics 33:159-174

32. Kornacka A, Cybulska A, Bień J, Goździk K, Moskwa B (2016) The usefulness of direct agglutination test, enzyme-linked immunosorbent assay and polymerase chain reaction for the detection of Toxoplasma gondii in wild animals. Vet Parasitol 228:85-89. https://doi.org/10.1016/j.vetpar.2016.08.010

33. Lehmann T, Marcet PL, Graham DH, Dahl ER, Dubey JP (2006) Globalization and the population structure of Toxoplasma gondii. Proc Natl Acad Sci USA 103:11423-11428

34. Schares G, Koethe M, Bangoura B, Geuthner AC, Randau F, Ludewig M, Maksimov P, Sens M, Bärwald A, Conraths FJ, Villena I, Aubert D, Opsteegh M, Van der Giessen J (2018) Toxoplasma gondii infections in chickens - performance of various antibody detection techniques in serum and meat juice relative to bioassay and DNA detection methods. Int J Parasitol 48:751-762. https://doi.org/10.1016/j.ijpara.2018.03.007 
35. Shwab EK, Zhu XQ, Majumdar D, Pena HF, Gennari SM, Dubey JP, Su C (2014) Geographical patterns of Toxoplasma gondii genetic diversity revealed by multilocus PCR-RFLP genotyping. Parasitol 141:453-461

36. Verma SK, Ajzenberg D, Rivera-Sanchez A, Su C, Dubey JP (2015) Genetic characterization of Toxoplasma gondii Isolates from Portugal, Austria and Israel reveals higher genetic variability within the type II lineage. Parasitol 142:948-957. https://doi. org/10.1017/s0031182015000050

37. Vieira FEG, Sasse JP, Minutti AF, Miura AC, de Barros LD, Car$\operatorname{dim}$ ST, Martins TA, de Seixas M, Yamamura MI, Su C, Garcia JL (2018) Toxoplasma gondii: prevalence and characterization of new genotypes in free-range chickens from South Brazil. Parasitol Res 117:681-688. https://doi.org/10.1007/s00436-017-5730-5
38. Wang L, Cheng HW, Huang KQ, Xu YH, Li YN, Du J, Yu L, Luo QL, Wei W, Jiang L, Shen JL (2013) Toxoplasma gondii prevalence in food animals and rodents in different regions of China: isolation, genotyping and mouse pathogenicity. Parasit Vectors $6: 273$

Publisher's Note Springer Nature remains neutral with regard to jurisdictional claims in published maps and institutional affiliations. 